\title{
RESPONSE OF WHEAT-MAIZE YIELDS AND THEIR NUTRIENTS STATUS TO THE APPLICATION OF NATURAL MINERALS UNDER CONDITIONS OF BOTH ORGANIC MANURING AND BIOFERTILIZATION \\ El-Etr, Wafaa T. ; Gehan H. Youssef and Mona A. Osman \\ Soils, Water and Environ. Res. Inst., Agric. Res. Center (ARC), Giza, Egypt
}

\begin{abstract}
Calcareous soil is relatively poor in plant nutrients and organic contents. Such great problem may be solved by applying organic manure and natural minerals. Therefore, using natural sources (NS), either mineral or rock (feldspar, magnetite ore including certain micronutrients (MO) and rock phosphate), may be considered a specific management program for reducing the needs for imported chemical fertilizers which are expensive than those natural ones. Four treatments which were:- 1- Either rice straw compost (RSC) or farmyard manure (FYM) alone, 2- RSC enriched with macronutrients or FYM enriched with macronutrients (RSC+Ma or FYM+Ma), 3- RSC enriched with Micronutrients or FYM enriched with Micronutrients (RSC+Mi or $\mathrm{FYM}+\mathrm{Mi}$ ) and 4- Organic sources (RSC or FYM) enriched with macronutrients and micronutrients supply (ERSC and EFYM). These treatments were either un-inoculated or inoculated with a mixture of phosphorus, potassium and calcium dissolving bacteria to study the effects of these treatments on macronutrients availability in soil, nutritional status and yield components of both wheat and maize crops.

Results showed general high significant increases for available N, P and $\mathrm{K}$, yields (straw and grains) of both wheat and maize along with their total content of the indicated macronutrients due to the application of ERSC in presence of inoculation as compared to RSC alone (without application of macro or micro elements). With regard to effect of inoculation with dissolving nutrients bacteria, there was insignificant effect on the studied parameters through the two studied seasons. In spite of that, the inoculation was superior more than non-inoculation. As far as applied organic sources, results indicated that values representing parameters studied for both crops more increased due to adding the RSC as compared to FYM. Moreover, positive effect of EOM treatment (average of ERSC and EFYM) on macronutrients availability in soil, their total content in plant and yield components for the two studied seasons was more positively affected significantly as compared to other treatments. Finally, data indicated that the ERSC can be used as a source of fertilization in presence of the nutrients dissolving bacteria in calcareous soils and expected to be economic as well as environmentally safe.
\end{abstract}

Keywords: Natural mineral; Feldspar; Rock phosphate; Slow release nitrogen fertilizer; Compost; Biofertilizers Calcareous soil.

\section{INTRODUCTION}

Most of newly reclaimed soils in Egypt are sandy and calcareous soils that are poor in available nutrients. Calcareous soils are considered to be limited in nutrients availability for plants whose growth suffers particularly from micronutrients deficiency due to many problems (Kulikova et al., 2002). In addition, increased nitrogen $(\mathrm{N})$ losses as ammonia and reduced solubility of phosphorus $(\mathrm{P})$ occur in these soils. In fact, nutrient availability in the soilplant system is dictated by complex interactions among plant roots, soil 


\section{El-Etr, Wafaa T. et al.}

microorganisms, chemical reactions and pathways of the indicated losses. Of course, the indicated interactions involve the processes of transformations induced by physical processes (leaching, runoff and volatilization), chemical reactions (exchange, fixation, precipitation and hydrolysis) and biological $\left(\mathrm{N}_{2}\right.$ fixation, nitrification, denitrification and immobilization). The extent by which the added nutrients or removed from soil solution by these processes, which compete with plant uptake, can affect both nutrients use efficiency and the environment (Jagadeeswaran, et al., 2007).

The efficiency of nitrogen fertilizer can be increased through the use of slow release nitrogen forms, which potentially reduce nitrogen leaching losses particularly from sandy soils, extend $\mathrm{N}$ availability over the growing season and improve the efficiency of plant recovery (Wang and Alva, 1996). Recently, Osman and Abd El-Rahman (2009) found that the application of urea-formaldehyde (UF) and phosphorus coated urea (PCU) fertilizers improved the studied parameters of guava tree growth and leaf mineral content. Also Hassan et al., (2010) showed that urea-formaldehyde (UF) treatments, either as full or half dose, had positive effects on vegetative growth parameters for the studied trees (grape, mango, banana and date palm), along with leaf mineral content. The authors added that UF treatments increased the available forms of N, P and K in the soil of the four grown crops seedlings in comparison with the traditional urea.

Combined application of urea and farmyard manure was reported by Gupta et al., (2000) and Selim (2004) who studied the use of three nitrogen fertilizaers (ammonium sulphate, urea formaldehyde and chicken manure) under different irrigation systems in sandy calcareous soils. They found that, ammonium sulphate and urea formaldehyde treatments gave more straw and grains yield of wheat. Urea formaldehyde and chicken manure treatments recorded higher $\mathrm{N}, \mathrm{P}$ and $\mathrm{K}$ contents for both straw and grains than ammonium sulphate treatment. Urea formaldehyde gave a systematic increase in utilization efficiency by increasing $\mathrm{N}$ - dose.

Sharma et al., (1995) reported that agronomic effectiveness of rock phosphate (RP) increased by the use of farmyard manure; application of recommended level of $\mathrm{P}\left(90 \mathrm{Kg} \mathrm{P}_{2} \mathrm{O}_{5} \mathrm{ha}^{-1}\right)$ through $\mathrm{RP}$ application in conjunction with farmyard manure gave significantly higher wheat yield and P-uptake than the control.

According to Buchholz and Brown (1993), more than 98\% of potassium in soil exists in the form of silicate minerals (microcline, muscovite, orthoclase, biotite and feldspars, etc.). Potassium and other metal elements can be released when these minerals are slowly weathered. In spite of that, the most important sources of potassium in soil are the primary aluminosilicates, which include K-feldspar.

Abdel Wahab et al., (2003), declared that the highest values of plant growth parameters were obtained in case of organic compost application in combination with either chemical or natural sources of potassium as feldspar. Also, Badr et al., (2006) recorded that the use of feldspar and compost in the field was found to be economic as well as environmentally safe. Finally, Wahba and Darwish (2008) reported that the addition of both compost and feldspar each individually or both together increased available potassium 
content as compared to control, the response being dependent on the used soil.

The effectiveness of FYM enriched with micronutrients was previously discussed by Basyouny (2001) who reported that FYM mixed with $\mathrm{Fe}$ and $\mathrm{Zn}$ gave the highest increases in shoot dry weight at the first and second stages of growth and also the highest straw and grain yields of both wheat and maize.

Farmyard manure has played an important role in the continuous supply of well- balanced diets of nutrients to crops, and represents an important component of the nutrients cycle in agricultural ecosystems. However, the use of FYM alone may not be enough to meet the enormous nutrient requirements of present-day high yielding cultivars. Thus, integrated nutrient management, in which both organic manures and inorganic fertilizers are used simultaneously, has been suggested as the most effective method to maintain a healthy and sustainable soil system with relatively high crop productivity (Palm et al., 1997).

Micro-organisms are important components in the natatural soil subecosystem because they not only can contribute to nutrient availability in the soil, but also help to bind soil particles into stable aggregates (Shetty et al., 1994). Seddik, (2001) showed that microorganisms solubilize the minerals by direct enzymatic attack promoting the degradation through their metabolites. Co-inoculation of phosphate solubilizing bacteria (PSB) and potassium solubilizing bacteria (KSB) in conjunction with direct application of rock $P$ and $K$ minerals into the soil increased $N, P$ and $K$ uptake, photosynthesis and the yield of eggplant grown on limited $\mathrm{P}$ and $\mathrm{K}$ soil, (Han and Lee, 2005). Also, Wu et al., (2005) found that the application of bacterial biofertilizer containing an arbuscular mycorrhizal fungus increased significantly the growth of Zea mays and nutritional assimilation of plant (Total $\mathrm{N}, \mathrm{P}$ and $\mathrm{K}$ ); it also improved soil properties. Recently, trials with rhizosphere- associated plant growth-promoting $\mathrm{N}_{2}$-fixing and p-solubilising Bacillus species indicated yield increases in maize and wheat (Cakmakcl et al., 2007).

The objective of the present study is to evaluate the efficiency of using natural sources (urea formaldehyde (UF), rock phosphate (RP), feldspar and magnetite ore including certain micronutrients (MO)) accompanied with organic sources (rice straw compost, RSC and/or farmyard manure, FYM) in presence of the nutrient dissolving bacteria (composite inoculum of various associative diazotrophs and some of $\mathrm{P}, \mathrm{K}$ and $\mathrm{Ca}$ dissolving bacteria) adopted for wheat and maize plants grown on calcareous soil.

\section{MATERIALS AND METHODS}

A field experiment was carried out at Noubaria Agriculture Research station farm during two successive seasons, winter season 2007 / 2008 with wheat (Triticum aestivum L., cv Giza 168) and summer season 2008 with maize (Zea mays L., cv Giza 10), to study the effect of some organic sources, natural materials and slow release fertilizer along with inoculation with some 
$\mathrm{P}, \mathrm{K}$ and $\mathrm{Ca}$ dissolving bacteria on chemical properties of soil and nutritional status of grown wheat and maize yields.

Some physical and chemical characteristics of the studied soil are shown in Table 1; those of rice straw compost (RSC), farmyard manure (FYM) and natural sources (NS) are described in (Table 2).

Wheat and maize were cultivated in a randomized split- split plot design with plot dimensions of $3.0 \times 3.5 \mathrm{~m}$ (plot area $10.5 \mathrm{~m}^{2}$ ); each treatment was replicated three times. The main plots were either un-inoculated or inoculated with phosphorus, potassium and calcium dissolving bacteria. The sub main plots represented treatments of organic sources (rice straw compost, RSC and farmyard manure, FYM) which were added at the rate of $20 \mathrm{~m}^{3} \mathrm{fed}^{-1}$. The sub-sub plots standed for four treatments as following:-

1- Rice straw compost (RSC) or farmyard manure (FYM), each of them supplemented with mineral fertilizer.

2- Rice straw compost (RSC) or farmyard manure (FYM), each of them supplemented with macronutrients $(\mathrm{N}, \mathrm{P}$ and $\mathrm{K}$ ) in the forms of urea formaldehyde, rock phosphate and feldspar $(\mathrm{RSC}+\mathrm{Ma}$ or $\mathrm{FYM}+\mathrm{Ma})$, respectively.

3- Rice straw compost (RSC) or farmyard manure (FYM), each of them supplemented with magnetite ore as a source of micronutrients i.e, $\mathrm{Fe}$, $\mathrm{Mn}, \mathrm{Zn}$ and Cu plus mineral fertilizer (RSC + Mi or FYM + Mi)

4- Rice straw compost (RSC) or farmyard manure (FYM), each of them supplemented with natural minerals of both macro and micronutrients as above (ERSC or EFYM representing enriched fertilization treatments).

Table (1): Some physical and chemical properties of soil samples representing the studied location

\begin{tabular}{|c|c|c|}
\hline \multirow{2}{*}{\multicolumn{3}{|c|}{\begin{tabular}{|l} 
Soil characteristics \\
Particle size distribution \%
\end{tabular}}} \\
\hline & & \\
\hline Coarse sand & 9.68 & 12.2 \\
\hline Fine sand & 57.5 & 55.9 \\
\hline Silt & 15.7 & 16.0 \\
\hline Clay & 17.1 & 15.9 \\
\hline Texture class & Sandy loam & Sandy loam \\
\hline SP & 38.3 & 41.2 \\
\hline \multicolumn{3}{|l|}{ Chemical properties } \\
\hline $\mathrm{CaCO}_{3} \%$ & 50.4 & 30.6 \\
\hline $\mathrm{pH}$ (suspension 1:2.5) & 8.84 & 8.86 \\
\hline $\mathrm{EC} \mathrm{dSm}^{-1}$ (saturated paste extract) & 7.68 & 6.56 \\
\hline Organic matter \% & 0.51 & 1.78 \\
\hline \multicolumn{3}{|l|}{ Soluble cations and anions (Ceq $\mathrm{Kg}^{-1}$ ) } \\
\hline $\mathrm{Ca}^{++} \mathrm{Ca}$ & 15.1 & 37.3 \\
\hline $\mathrm{Mg}^{++}$ & 17.1 & 9.52 \\
\hline $\mathrm{Na}^{+}$ & 58.4 & 30.7 \\
\hline $\mathrm{K}^{+}$ & 2.54 & 1.16 \\
\hline $\mathrm{CO}_{3}^{--}$ & 1.99 & - \\
\hline $\mathrm{HCO}_{3}{ }^{-}$ & 7.12 & 14.6 \\
\hline $\mathrm{CL}^{-}$ & 56.3 & 34.9 \\
\hline $\mathrm{SO}_{4}^{--}$ & 27.7 & 29.2 \\
\hline \multicolumn{3}{|l|}{ Available nutrients $\left(\mathrm{mg} \mathrm{Kg}^{-1}\right)$} \\
\hline $\mathrm{N}$ & 21.0 & 30.0 \\
\hline$P$ & 28.6 & 20.0 \\
\hline $\mathrm{K}$ & 353 & 368 \\
\hline
\end{tabular}


Table (2): Analysis of organic sources, natural minerals constituents

\begin{tabular}{|l|c|c|c|c|c|}
\hline Determination & Compost & FYM & Feldspar & $\begin{array}{c}\text { Rock } \\
\text { phosphate }\end{array}$ & Magnetite \\
\hline $\mathrm{EC} \mathrm{dS} \mathrm{m} \mathbf{m}^{-1}$ & $6.61^{*}$ & $4.2^{*}$ & $0.44^{* *}$ & $3.07^{\star *}$ & $0.33^{* *}$ \\
\hline $\mathrm{pH}$ & $7.57^{*}$ & $8.7^{*}$ & $8.56^{* *}$ & $7.80^{* *}$ & $7.8^{* *}$ \\
\hline Organic matter \% & 56.6 & 28.8 & - & - & - \\
\hline Available nutrients $\left.\mathbf{( m g ~ K g}^{-1}\right)$ & & & & & \\
$\mathrm{N}$ & & & & & - \\
$\mathrm{P}_{2} \mathrm{O}_{5}$ & 512 & 414 & - & - & - \\
$\mathrm{K}_{2} \mathrm{O}$ & 2199 & 361 & - & 4.37 & - \\
$\mathrm{Fe}$ & 5245 & 631 & 191 & - & - \\
$\mathrm{Mn}$ & 14.2 & 44.3 & 13.9 & 9.02 & 22.0 \\
$\mathrm{Zn}$ & 113 & 44.9 & 3.22 & 2.19 & 7.48 \\
$\mathrm{Cu}$ & 16.3 & 15.0 & 0.59 & 1.13 & 2.70 \\
& 2.48 & 2.70 & 0.31 & 3.1 & 0.43 \\
\hline
\end{tabular}

${ }^{*}$ EC (1:10) org. fertilizer : water extract

** EC (1:5) mineral : water extract

${ }^{*} \mathrm{pH}(1: 10)$ org. fertilizer : water suspension $\quad{ }^{* \star} \mathrm{pH}(1: 2.5)$ mineral : water suspension

Natural minerals urea formaldehyde (UF), rock phosphate (RP), feldspar and magnetite ore (MO) were mixed with organic forms (rice straw compost or farmyard manure) to be one month incubated and finally applied before cultivation. They were, respectively, applied at rates of $300,100,800$ and 700 $\mathrm{Kg} \mathrm{fed}^{-1}$. The treatments were thoroughly mixed with the surface soil layer (0$15 \mathrm{~cm}$ ) of the concerned plots.

Before cultivation, both of wheat and maize plants, the plots received either rice straw compost (RSC) or farmyard manure (FYM) as well as those received RSC or FYM enriched with micronutrients were supplemented with inorganic fertilizers as follows: ammonium nitrate $(33 \% \mathrm{~N})$ at rate of 100 and $120 \mathrm{Kg}$ fed.-1 of $\mathrm{N}$ for wheat and maize plant, respectively. Superphosphate $\left(15 \% \mathrm{P}_{2} \mathrm{O}_{5}\right)$ and potassium sulfate $\left(48 \% \mathrm{~K}_{2} \mathrm{O}\right)$ at rates of 30 and $48 \mathrm{Kg} \mathrm{fed}^{-1}$ of $\mathrm{P}_{2} \mathrm{O}_{5}$ and $\mathrm{K}_{2} \mathrm{O}$, respectively for both plants. Phosphorus and potassium fertilizers were added before planting, ammonium nitrate being added in four equal split doses after planting.

Treatments were either non-inoculated or inoculated with a composite inoculum of various associative diazotrophs and some of $\mathrm{P}, \mathrm{K}$ and Ca dissolving bacteria. The composite inoculum included two associative $\mathrm{N}_{2}$ fixing bacterial strains of Azotobacter chroococcum and Bacillus polymyxa along with one P-dissolving bacteria strain of Bacillus megatherium and one K- dissolving bacteria strain of Bacillus circulans. All strains were obtained from the culture collection of Biofertilizer Unit, Cairo Mircen, Microbiological Resource Center, Ain Shams University. Three most effective $\mathrm{Ca}$-solubilized bacteria isolates, i.e., NBa7, NPS9 and Nsr13 were selected from several isolates taken from Nobaria soils.

For the composite inoculum, each strain and isolate was separately grown on combined C-source liquid culture medium, CCM (Hegazi et al., 1998); $P$ and $K$ dissolving bacteria were separately grown on N.B medium (Youssef, 1993) with Ca dissolving isolates being separately grown on Ashby modified medium (Hegazi and Niemela, 1976) and the calcium carbonate zones diameter were determined. Isolates were incubated for 3-5 days at 30 ${ }^{\circ} \mathrm{C}$ with continuous shaking; equal volumes of the individual liquid cultures 


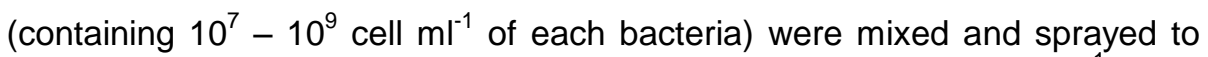
the complete cover of over the concerned seeds, at the rate of $1 \mathrm{~L} \mathrm{plot}^{-1}$.

Both plants and soil were sampled at 150 days after sowing for wheat and 120 days after sowing for maize, which represent their harvesting stages.

Surface soil samples (0-15 cm depth) were subjected to analyses of $\mathrm{CaCO}_{3}$, soil $\mathrm{pH}$, organic matter content and available nutrients $(\mathrm{N}, \mathrm{P}$ and $\mathrm{K})$ according to Page et al., (1982).

Samples of both straw and grains were oven dried at $70^{\circ} \mathrm{C}$, up to a constant dry weight, ground and prepared for digestion. The digests were then subjected to the evaluation of nutrients ( $N, P$ and $K$ ) according to procedures described by Cottenie et al., (1982).

Obtained results were subjected to statistical analysis according to Snedecor and Cochran (1980) and the treatments were compared by using least significant difference comparison (L.S.D.).

\section{RESULTS AND DISCUSSION}

1- Nutrients availability in soil after harvesting of both wheat and maize:

The data representing availability of soil nutrients $(\mathrm{N}, \mathrm{P}$ and $\mathrm{K})$ after wheat and maize harvesting are shown in Table (3). Statistical interaction analyses showed that all applied treatments increase more significantly the soil nutrients availability ( $\mathrm{N}, \mathrm{P}$ and $\mathrm{K}$ ) compared to the control treatment; this trend was true for both crops. Application of enriched rice straw compost (ERSC) in presence of inoculation was significantly superior for both crops; the corresponding increases as compared to rice straw compost (RSC) applied alone for the studied elements were $42.9 \%, 94.7 \%$ and $59.2 \%$ as well as $43.2 \%, 69.1 \%$ and $26.4 \%$ for wheat and maize crops, respectively. In spite of that, application of farmyard manure (FYM) without inoculation was generally significantly inferior.

Obtained results may be due to the application of urea formaldehyde (UF) which should affect soil pH. The dissolved nitrogen should diffuse back out gradually through the environment (Kirk, 1993). Slow-release nitrogen (N) materials are often used to reduce $\mathrm{N}$ leaching losses from sandy soils (Wang and Alva, 1996) and extend $\mathrm{N}$ availability over the growing season. Later on, Jagadeeswaran et al., (2007) found that the slow release of nitrogen coupled with reduced losses due to $\mathrm{NH}_{3}$ volatilization and leaching had evidently maintained nitrogen status as well as nitrogen uptake from the urea formaldehyde. Of course, the increase in available $P$ could be attributed to mineralization of organic $P$ of rice straw, solubilization action of certain organic acids and displacement of phosphate with organic anions. Hellal and Nagumo (2009) proved the increase for the P solubility from rock phosphate during composting of rice straw and its significant effects on maize growth.

Finally, Singh et al., (2002) found that application of farmyard manure increased the crop uptake of potassium. Indeed, microorganisms catalyze oxidation of organic matter in calcareous soil and, if representing organic matter by carbohydrate $\left(\mathrm{CH}_{2} \mathrm{O}\right)$, the reaction is: $\mathrm{CH}_{2} \mathrm{O}+\mathrm{O}_{2} \longrightarrow \mathrm{CO}_{2}+\mathrm{H}_{2} \mathrm{O}$. The carbon dioxide and water can then combine and form carbonic acid 
which again with calcium carbonate leads to the production of more carbon dioxide. Such $\mathrm{CO}_{2}$ can break down many common minerals to release elements.

$\mathrm{H}_{2} \mathrm{CO}_{3}+\mathrm{CaCO}_{3} \longrightarrow \mathrm{CO}_{2}+\mathrm{H}_{2} \mathrm{O}$

$2 \mathrm{KAISi}_{3} \mathrm{O}_{8}+2 \mathrm{H}+2 \mathrm{HCO}_{2}+\mathrm{H}_{2} \mathrm{O} \longrightarrow \mathrm{Al}_{2} \mathrm{Si}_{2} \mathrm{O}_{5}(\mathrm{OH})_{4}+2 \mathrm{~K}++2 \mathrm{HCO}_{3}^{-}+4 \mathrm{SiO}_{2}$

Table (3): The available nutrients $\left(\mathrm{mg} \mathrm{Kg}^{-1}\right)$ under different treatments of tested soil for both wheat and maize plants

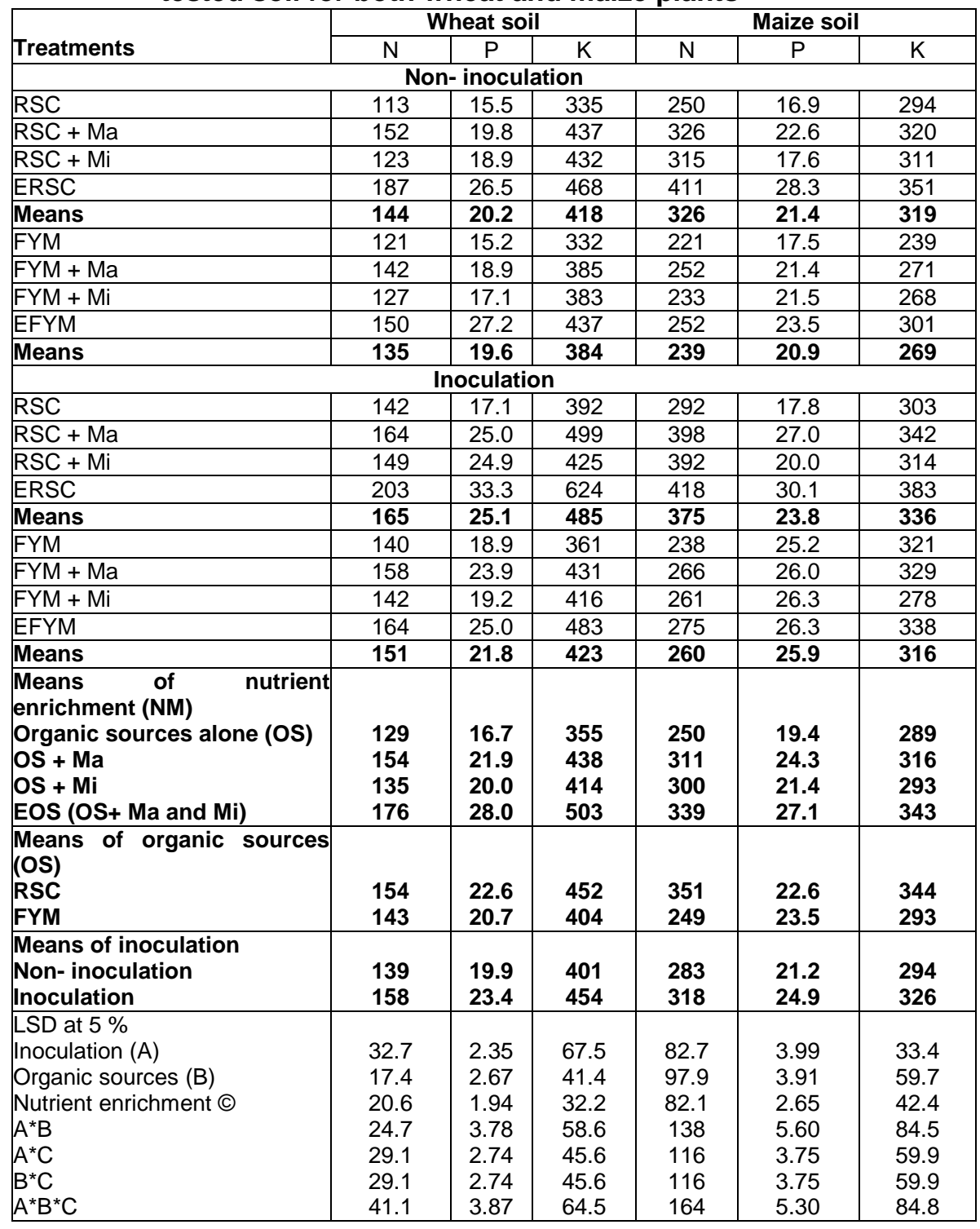

RSC: Rice straw compost, FYM: farmyard manure, Ma: macronutrients, Mi: micronutrients, ERSC: enriched rice straw compost, EFYM: enriched farmyard manure, NM: natural minerals, OS: organic sources, EOS: enriched organic sources 
Wahba and Darwish (2008) added that feldspar with presence of compost mixture increased the potassium availability. Previous studies emphasized that decomposition of organic matter produces several organic acids such as acetic, butyric and formic acids, able to specifically break down a mineral structure as to extract the concerned elements (Sheng et al., 2003). The hydrolysis processes may be considered mechanisms that help on releasing potassium from feldspar. In the presence of water, orthoclase hydrolyzes to kaolinite with $\mathrm{K}$ release:

$2 \mathrm{KAISi}_{3} \mathrm{O}_{8}+11 \mathrm{H}_{2} \mathrm{O} \longrightarrow \mathrm{Al}_{2}\left(\mathrm{Si}_{2} \mathrm{O}_{5}\right)(\mathrm{OH})_{4}+4 \mathrm{Si}(\mathrm{OH})_{4}+2 \mathrm{~K}^{+}+2 \mathrm{OH}^{-}$

The released potassium ions may be absorbed and utilized by grown plants or other organisms, adsorbed on to the negatively charged surfaces of humus or phyllosilicate clay colloids in the soil or leached into the ground water.

To differentiate between influence of $\mathrm{Ma}$ and that of $\mathrm{Mi}$, results showed that, regardless of the organic source (RSC or FYM), enrichment with macronutrients $(\mathrm{Ma})$ was, as expected, more effective than the enrichment with micronutrients (Mi) for improving the availability of the correspondent macro nutrients in soil, particularly in presence of inoculation with dissolving nutrients bacteria.

Finally, it was found to be there discuss each of the studied factors separately. Irrespective of effect of both organic sources and inoculation, different natural minerals treatments on nutrients availability in soil, the enriched organic source (EOS) treatment achieved more significant increases as compared to organic source applied alone. Treatments may be arranged as follows: $\mathrm{EOS}>\mathrm{OS}+\mathrm{Ma}>\mathrm{OS}+\mathrm{Mi}>\mathrm{OS}$ alone for both wheat and maize crops.

With regard of organic source, the results indicate that application of rice straw compost generally increased the values of available macronutrients for both wheat and maize, despite the absence of significancy between both applied organic sources (RSC and FYM). Such results are confirmed by those of Abd El Hamid et al., (2004) who reported that the addition of compost (20-200 $\left.\mathrm{g} \mathrm{pot}^{-1}\right)$ improved, in the long run, soil chemical properties, total $\mathrm{N}$, total $\mathrm{C}$ and CEC as well as soil fertility as a whole.

With respect to inoculation with dissolving nutrients bacteria, results show increases in the available macronutrients values as compared to noninoculation conditions. The bacteria may produce bacterial acids, alkalies or chelants that should enhance the release of elements from natural minerals (Sugumaran and Janarthanam, 2007).

2- Responses of yield components for both wheat and maize crops to application of different natural minerals, organic manures and inoculation with bacteria.

Statistical interaction analyses of data in Table (4) show that wheat yields receiving the enriched nutrients combined with farmyard manure (EFYM) in presence of inoculation with dissolving nutrients bacteria were significantly the highest compared to other treatments, enriched nutrients combined with rice straw compost (ERSC) being the superior regarding maize yields. Increases in yield components of wheat plants, as compared to FYM alone, recorded $30.1 \%$ and $61.6 \%$ for straw and grains, respectively; the corresponding increases in straw and grains of maize plants, as compared to 
RSC alone, recorded $42.7 \%$ and $23.1 \%$, respectively. On the other hand, the most inferior treatments for both two yield components were recorded for the FYM alone without inoculation.

Table (4): Response of yield components (Kg fed. $\left.{ }^{-1}\right)$ for both wheat and maize to application of different natural minerals, organic manures and bacteria inoculation

\begin{tabular}{|c|c|c|c|c|}
\hline \multirow[t]{2}{*}{ Treatments } & \multicolumn{2}{|c|}{ Wheat yield } & \multicolumn{2}{|c|}{ Maize Yield } \\
\hline & Straw & Grains & Straw & Grains \\
\hline \multicolumn{5}{|c|}{ Non- inoculation } \\
\hline RSC & 5543 & 1006 & 2917 & 586 \\
\hline $\mathrm{RSC}+\mathrm{Ma}$ & 5880 & 1344 & 3777 & 649 \\
\hline $\mathrm{RSC}+\mathrm{Mi}$ & 5850 & 1306 & 3274 & 611 \\
\hline ERSC & 6497 & 1542 & 4003 & 676 \\
\hline Means & 5943 & 1299 & 3493 & 630 \\
\hline FYM & 5263 & 944 & 2263 & 489 \\
\hline $\mathrm{FYM}+\mathrm{Ma}$ & 5793 & 1105 & 2940 & 570 \\
\hline FYM + Mi & 5487 & 972 & 2553 & 527 \\
\hline EFYM & 6627 & 1614 & 2930 & 592 \\
\hline Means & 5793 & 1159 & 2672 & 545 \\
\hline \multicolumn{5}{|c|}{ Inoculation } \\
\hline RSC & 5720 & 1273 & 3083 & 644 \\
\hline $\mathrm{RSC}+\mathrm{Ma}$ & 6647 & 1368 & 4130 & 730 \\
\hline $\mathrm{RSC}+\mathrm{Mi}$ & 6303 & 1319 & 3897 & 700 \\
\hline ERSC & 7100 & 1736 & 4400 & 793 \\
\hline Means & 6443 & 1424 & 3878 & 717 \\
\hline FYM & 5540 & 1159 & 2727 & 541 \\
\hline $\mathrm{FYM}+\mathrm{Ma}$ & 6680 & 1351 & 2977 & 563 \\
\hline FYM + Mi & 6357 & 1220 & 2300 & 535 \\
\hline EFYM & 7210 & 1873 & 3300 & 644 \\
\hline Means & 6447 & 1401 & 2826 & 571 \\
\hline $\begin{array}{l}\text { Means of nutrient enrichment } \\
(\mathrm{NM}) \\
\text { Organic source alone }(\mathrm{OS}) \\
\mathrm{OS}+\mathrm{Ma} \\
\mathrm{OS}+\mathrm{Mi} \\
\text { EOS (OS+Ma and Mi) }\end{array}$ & $\begin{array}{l}5517 \\
6250 \\
5999 \\
6858 \\
\end{array}$ & $\begin{array}{l}1095 \\
1292 \\
1204 \\
1691 \\
\end{array}$ & $\begin{array}{l}2748 \\
3456 \\
3006 \\
3658 \\
\end{array}$ & $\begin{array}{l}565 \\
628 \\
593 \\
677 \\
\end{array}$ \\
\hline $\begin{array}{l}\text { Means of organic source (OS) } \\
\text { RSC } \\
\text { FYM }\end{array}$ & $\begin{array}{l}6193 \\
6119 \\
\end{array}$ & $\begin{array}{l}1362 \\
1279 \\
\end{array}$ & $\begin{array}{l}3685 \\
2749 \\
\end{array}$ & $\begin{array}{l}674 \\
558 \\
\end{array}$ \\
\hline $\begin{array}{l}\text { Means of inoculation } \\
\text { Non- inoculation } \\
\text { Inoculation } \\
\end{array}$ & $\begin{array}{l}5868 \\
6445 \\
\end{array}$ & $\begin{array}{l}1229 \\
1412 \\
\end{array}$ & $\begin{array}{l}3082 \\
3352 \\
\end{array}$ & $\begin{array}{l}588 \\
644 \\
\end{array}$ \\
\hline $\begin{array}{l}\text { LSD at } 5 \% \\
\text { Inoculation }(A) \\
\text { Organic source (B) } \\
\text { Nutrient enrichment C) } \\
A \text { * } B \\
A * C \\
B \text { * C } \\
A * B * C\end{array}$ & $\begin{array}{l}1415 \\
994 \\
951 \\
1406 \\
1346 \\
1346 \\
1903 \\
\end{array}$ & $\begin{array}{l}193 \\
231 \\
217 \\
327 \\
308 \\
308 \\
436\end{array}$ & $\begin{array}{l}684 \\
555 \\
418 \\
786 \\
591 \\
591 \\
836\end{array}$ & $\begin{array}{l}84.7 \\
129 \\
74.9 \\
183 \\
106 \\
106 \\
150 \\
\end{array}$ \\
\hline
\end{tabular}

RSC: Rice straw compost, FYM: farmyard manure, Ma: macronutrients, Mi: micronutrients, ERSC: enriched rice straw compost, EFYM: enriched farmyard manure, NM: natural minerals, OS: organic sources, EOS: enriched organic sources 


\section{El-Etr, Wafaa T. et al.}

These data agree with results reported by Hassan et al., (2010) who found that urea formaldehyde treatment had a positive effect on plant growth parameters.

In this respect, Ramilison (2001) found that maize grain yield increased with rock phosphate treatments at 150 and $300 \mathrm{Kg} / \mathrm{ha}$. Also, he reported that the interaction between rock phosphate and organic manure showed significant effect on grain yield especially with the high concentration of rock phosphate. Later on, Nishanth and Biswas (2007) reported that additions of diammonium phosphate or enriched composts resulted in highly significant increases for shoot, root and total yield within the growth stages of wheat as compared to control. Kawthar et al., (2010) showed that the combination of compost (20 ton/fed) and rock phosphate $(1000 \mathrm{Kg} / \mathrm{fed})$ gave the highest values of morphological parameters. Their improvement in growth resulted from organic fertilization which stimulates the absorption of nutrients and their reflection on photosynthesis process which certainly reflected positively on both growth and yield.

Also, the responsibility of growth and yield should be improved as a result of the interaction between bio and natural fertilizers (rock phosphate and feldspar), (Massoud et al., 2009).

Again, irrespective of effect of both organic matter forms and inoculation, data in Table (4) show that yields (straw, grains or seeds) of both wheat and maize were significantly higher with the application of different sources of nutrient elements (natural minerals) combined with organic fertilizers as compared to organic fertilizer alone. Increases in yield components of wheat plants, recorded respectively $24.3 \%$ and $54.4 \%$ against $33.1 \%$ and $19.8 \%$ for maize straw and grains; treatments can be arranged as follows: enriched organic source (EOS) > organic source enriched with macronutrients $(\mathrm{OS}+\mathrm{Ma})>$ organic source enriched with micronutrients (OS $+\mathrm{Mi})>$ organic source alone (OS). These results are in similar trend to those of enrichment with macronutrients in soil previously discussed.

Regarding the applied organic sources, results indicate that rice straw compost, as compared to FYM was superior for the yield components of both studied crops particularly for maize compared to wheat possibly attributed to high temperature more affecting the decomposition of compost as a result of the biological activities of microorganisms grown on the easily mineralizable organic matter available at the beginning of decomposition (Ali et al., 2003).

Finally, the yields of both wheat and maize increased by inoculation, as compared to non- inoculation in spite of the general non significancy. Such results are confirmed by those of Cakmakcl et al., (2007) who found that phytohormone-producing bacteria encouraged adventitious root formation. Rapid establishment of roots, whether by elongation of primary roots or by proliferation of lateral and adventitious roots, was beneficial to young barley seedlings. Plant growth promoting rhizobacteria inoculation may effectively increase the surface area of roots and root weight. Later on, Massoud et al., (2009) reported that snapbean inoculation with phosphorus and potassium solubilizing bacteria was favorable to plant height. 
3- Responses of macronutrients uptake (total content $\mathrm{Kg} \mathrm{fed}^{-1}$ ) for both wheat and maize crops to the application of different sources of natural minerals, organic manures and inoculation with bacteria.

The total content of macronutrients ( $N, P$ and $K)$ in the straw and grains wheat and maize plants, respectively, are shown in Table (5, A and B). Statistical interaction analyses show that values of $\mathrm{N}, \mathrm{P}$ and $\mathrm{K}$ were superior with the enriched rice straw compost (ERSC) in presence of inoculation system as compared to other treatments; however, responses were generally not significant. Increases in nutrient uptake (N, P and K) by wheat plants of ERSC, as compared to RSC alone, recorded $36.1 \%, 22.8 \%$ and $46.6 \%$ for straw and $43.4 \%, 67.7 \%$ and $42.3 \%$ for grains, respectively. Correspondent increases for total contents of $\mathrm{N}, \mathrm{P}$ and $\mathrm{K}$ of maize plants recorded $46.8 \%$, $43.9 \%$ and $69.6 \%$ for straw and $31.9 \%, 38.8 \%$ and $22.9 \%$ for grains, respectively. These results are in similar trend with those of yield components and with those of Han et al., (2006) who reported that the soil inoculation with potassium solubilizing bacteria significantly increased nutrients uptake in pepper and cucumber plants. Rock phosphate and feldspar can be solubilized or weathered under influence of physical and biological agents. The latter is performed by microorganisms which produce organic acids, phenolic compounds, protons and siderophores. Soluble organic acids affecting rock phosphate weathering in soils could be of either high molecular weight (humic substances) or low molecular weight produced by plant roots and soil microorganisms. The low molecular weight organic acids produced by plant roots and soil microorganisms are very effective in promoting mineral dissolution (Duponnois et al., 2005). On the other hand, the most inferior treatments for both two yields components were, generally, recorded for the FYM alone without inoculation.

Regarding the application of organic manure sources, obtained results generally show that applied rice straw compost, compared to FYM, was slightly more favorable for NPK total content for straw and grains of wheat and maize plants, respectively. These results are confirmed by those previously mentioned; high temperature leads to more increased decomposition of compost as a result of microorganisms activity.

Irrespective of effect of both organic sources and inoculation, values of NPK uptake were significantly more stimulated with application of enriched nutrient elements organic source (EOS) as compared to the other tested treatments. Again, obtained improvements could be explained on the bases that the main source of nutrient for plants growing under natural conditions comes from the weathering of minerals (e.g. feldspar or rock phosphate) and organic sources such as composts and plant residues. 
El-Etr, Wafaa T. et al.

Table (5): Response of macronutrients uptake (total content $\mathrm{Kg}$ fed..$^{-1}$ ) for both straw and grains of wheat and maize crops to application of different sources of natural minerals, organic manures and bacteria inoculation

(A): Wheat crop

\begin{tabular}{|c|c|c|c|c|c|c|}
\hline \multirow[t]{2}{*}{ Treatments } & \multicolumn{3}{|c|}{ Straw } & \multicolumn{3}{|c|}{ Grains } \\
\hline & $\mathrm{N}$ & $\mathrm{P}$ & $\mathrm{K}$ & $\mathrm{N}$ & $\mathrm{P}$ & $\mathrm{K}$ \\
\hline \multicolumn{7}{|c|}{ Non- inoculation } \\
\hline RSC & 117 & 33.2 & 130 & 25.3 & 3.47 & 28.6 \\
\hline $\mathrm{RSC}+\mathrm{Ma}$ & 132 & 39.5 & 141 & 32.8 & 5.23 & 38.8 \\
\hline $\mathrm{RSC}+\mathrm{Mi}$ & 124 & 34.2 & 126 & 32.1 & 5.44 & 38.1 \\
\hline ERSC & 155 & 39.4 & 145 & 38.2 & 6.92 & 45.6 \\
\hline Means & 132 & 36.6 & 135 & 32.1 & 5.27 & 37.8 \\
\hline FYM & 108 & 31.9 & 120 & 21.2 & 3.88 & 27.5 \\
\hline $\mathrm{FYM}+\mathrm{Ma}$ & 136 & 39.2 & 135 & 27.9 & 4.05 & 31.7 \\
\hline $\mathrm{FYM}+\mathrm{Mi}$ & 118 & 33.7 & 125 & 25.7 & 3.59 & 28.0 \\
\hline EFYM & 156 & 43.7 & 158 & 37.5 & 5.92 & 43.4 \\
\hline Means & 130 & 37.1 & 134 & 28.1 & 4.36 & 32.7 \\
\hline \multicolumn{7}{|c|}{ Inoculation } \\
\hline RSC & 122 & 38.2 & 118 & 33.4 & 5.11 & 35.2 \\
\hline $\mathrm{RSC}+\mathrm{Ma}$ & 154 & 42.5 & 156 & 36.1 & 6.66 & 38.9 \\
\hline $\mathrm{RSC}+\mathrm{Mi}$ & 139 & 39.6 & 146 & 34.2 & 6.03 & 37.1 \\
\hline ERSC & 166 & 46.9 & 173 & 47.9 & 8.57 & 50.1 \\
\hline Means & 145 & 41.8 & 148 & 37.9 & 6.59 & 40.3 \\
\hline FYM & 125 & 35.8 & 132 & 31.1 & 5.09 & 32.6 \\
\hline $\mathrm{FYM}+\mathrm{Ma}$ & 157 & 43.0 & 156 & 33.6 & 6.23 & 38.5 \\
\hline $\mathrm{FYM}+\mathrm{Mi}$ & 150 & 38.5 & 140 & 31.9 & 5.37 & 34.1 \\
\hline EFYM & 157 & 43.9 & 170 & 46.5 & 7.66 & 48.8 \\
\hline Means & 147 & 40.3 & 149 & 35.8 & 6.09 & 38.5 \\
\hline $\begin{array}{l}\text { Means of nutrient enrichment } \\
(\mathrm{NM}) \\
\text { Organic source alone (OS) } \\
\mathrm{OS}+\mathrm{Ma} \\
\mathrm{OS}+\mathrm{Mi} \\
\text { EOS (OS+ Ma and Mi) }\end{array}$ & $\begin{array}{l}118 \\
145 \\
133 \\
158\end{array}$ & $\begin{array}{l}34.8 \\
41.0 \\
36.5 \\
43.5\end{array}$ & $\begin{array}{l}125 \\
144 \\
137 \\
162\end{array}$ & $\begin{array}{l}27.8 \\
32.6 \\
30.9 \\
42.5\end{array}$ & $\begin{array}{l}4.39 \\
5.54 \\
5.11 \\
7.27\end{array}$ & $\begin{array}{l}30.9 \\
37.0 \\
34.3 \\
46.9\end{array}$ \\
\hline $\begin{array}{l}\text { Means of organic source (OS) } \\
\text { RSC } \\
\text { FYM }\end{array}$ & $\begin{array}{l}139 \\
139 \\
\end{array}$ & $\begin{array}{l}39.2 \\
38.7\end{array}$ & $\begin{array}{l}142 \\
142 \\
\end{array}$ & $\begin{array}{l}34.9 \\
31.9 \\
\end{array}$ & $\begin{array}{l}5.93 \\
5.23\end{array}$ & $\begin{array}{l}39.1 \\
35.6 \\
\end{array}$ \\
\hline $\begin{array}{l}\text { Means of inoculation } \\
\text { Non- inoculation } \\
\text { Inoculation }\end{array}$ & $\begin{array}{l}131 \\
146 \\
\end{array}$ & $\begin{array}{l}36.9 \\
41.0 \\
\end{array}$ & $\begin{array}{l}135 \\
149 \\
\end{array}$ & $\begin{array}{l}30.0 \\
36.9 \\
\end{array}$ & $\begin{array}{l}4.82 \\
6.34 \\
\end{array}$ & $\begin{array}{l}35.2 \\
39.4 \\
\end{array}$ \\
\hline $\begin{array}{l}\text { LSD at } 5 \% \\
\text { Inoculation }(\mathrm{A})\end{array}$ & 28.2 & 7.97 & 46.2 & 4.68 & 1.04 & 5.63 \\
\hline Organic source $(\mathrm{B})$ & 17.4 & 4.57 & 22.7 & 5.39 & 0.87 & 5.18 \\
\hline Nutrient enrichment (C) & 22.2 & 7.38 & 23.5 & 5.63 & 1.15 & 6.06 \\
\hline$A^{*} B$ & 24.6 & 6.47 & 32.2 & 7.63 & 1.23 & 7.32 \\
\hline$A^{*} C$ & 31.4 & 10.4 & 33.3 & 7.96 & 1.62 & 8.57 \\
\hline $\mathrm{B}^{*} \mathrm{C}$ & 31.4 & 10.4 & 33.3 & 7.96 & 1.62 & 8.57 \\
\hline$A^{*} B^{\star} C$ & 44.3 & 14.8 & 47.1 & 11.3 & 2.29 & 12.1 \\
\hline
\end{tabular}


J. Soil Sci. and Agric. Eng., Mansoura Univ., Vol. 2 (9), September, 2011

(B): Maize crop

\begin{tabular}{|c|c|c|c|c|c|c|}
\hline \multirow[t]{2}{*}{ Treatments } & \multicolumn{3}{|c|}{ Straw } & \multicolumn{3}{|c|}{ Grains } \\
\hline & $\mathrm{N}$ & $\mathrm{P}$ & $\mathrm{K}$ & $\mathrm{N}$ & $P$ & $\mathrm{~K}$ \\
\hline \multicolumn{7}{|c|}{ Non- inoculation } \\
\hline RSC & 48.5 & 12.1 & 68.1 & 10.2 & 2.62 & 16.7 \\
\hline $\mathrm{RSC}+\mathrm{Ma}$ & 65.4 & 19.4 & 85.6 & 11.8 & 3.19 & 18.6 \\
\hline $\mathrm{RSC}+\mathrm{Mi}$ & 63.9 & 14.0 & 68.8 & 10.9 & 3.17 & 17.4 \\
\hline ERSC & 84.1 & 19.1 & 88.1 & 12.9 & 2.93 & 19.5 \\
\hline Means & 65.5 & 16.2 & 77.6 & 11.5 & 2.98 & 18.1 \\
\hline FYM & 43.9 & 11.3 & 50.8 & 9.07 & 2.36 & 13.8 \\
\hline $\mathrm{FYM}+\mathrm{Ma}$ & 60.4 & 15.0 & 67.0 & 11.4 & 2.99 & 16.1 \\
\hline $\mathrm{FYM}+\mathrm{Mi}$ & 49.9 & 11.1 & 58.3 & 9.70 & 2.32 & 15.0 \\
\hline EFYM & 60.3 & 14.6 & 68.7 & 11.1 & 2.82 & 16.7 \\
\hline Means & 53.6 & 12.9 & 61.2 & 10.3 & 2.62 & 15.4 \\
\hline \multicolumn{7}{|c|}{ Inoculation } \\
\hline RSC & 58.8 & 15.5 & 61.9 & 11.6 & 3.04 & 18.7 \\
\hline $\mathrm{RSC}+\mathrm{Ma}$ & 82.4 & 18.1 & 88.1 & 14.3 & 3.73 & 20.9 \\
\hline $\mathrm{RSC}+\mathrm{Mi}$ & 74.5 & 18.3 & 94.9 & 13.5 & 3.48 & 20.1 \\
\hline ERSC & 86.3 & 22.3 & 105 & 15.3 & 4.22 & 23.0 \\
\hline Means & 75.5 & 18.6 & 87.5 & 13.7 & 3.62 & 20.7 \\
\hline FYM & 53.3 & 12.4 & 63.6 & 9.87 & 2.78 & 15.5 \\
\hline $\mathrm{FYM}+\mathrm{Ma}$ & 61.4 & 14.8 & 68.2 & 11.1 & 3.43 & 16.3 \\
\hline $\mathrm{FYM}+\mathrm{Mi}$ & 47.3 & 10.3 & 49.6 & 9.73 & 2.56 & 15.0 \\
\hline EFYM & 62.4 & 14.8 & 76.4 & 12.3 & 3.05 & 18.5 \\
\hline Means & 56.1 & 13.1 & 64.5 & 10.7 & 2.96 & 16.3 \\
\hline \multicolumn{7}{|c|}{$\begin{array}{l}\text { Means of nutrient enrichment } \\
\text { (NM) }\end{array}$} \\
\hline Organic source alone (OS) & 51.1 & 12.8 & 61.1 & 10.2 & 2.70 & 16.2 \\
\hline $\mathrm{OS}+\mathrm{Ma}$ & 68.4 & 16.8 & 77.2 & 12.1 & 3.34 & 17.9 \\
\hline $\mathrm{OS}+\mathrm{Mi}$ & 58.9 & 13.4 & 67.9 & 10.9 & 2.88 & 16.9 \\
\hline EOS $(O S+M a$ and $M i)$ & 72.3 & 17.7 & 84.6 & 12.9 & 3.25 & 19.5 \\
\hline \multicolumn{7}{|l|}{ Means of organic source (OS) } \\
\hline $\begin{array}{l}\text { RSC } \\
\text { FYM }\end{array}$ & 70.5 & 17.4 & 82.6 & 12.6 & 3.30 & 19.4 \\
\hline & 54.9 & 13.0 & 62.8 & 10.5 & 2.79 & 15.9 \\
\hline \multicolumn{7}{|l|}{ Means of inoculation } \\
\hline Non- inoculation & 59.6 & 14.6 & 69.4 & 10.9 & 2.80 & 16.8 \\
\hline Inoculation & 65.8 & 15.8 & 75.9 & 12.2 & 3.29 & 18.5 \\
\hline \multicolumn{7}{|l|}{ LSD at $5 \%$} \\
\hline Inoculation $(A)$ & 5.31 & 1.37 & 15.6 & 1.54 & 0.71 & 2.22 \\
\hline Organic source (B) & 10.1 & 2.93 & 14.6 & 2.24 & 0.49 & 3.84 \\
\hline Nutrient enrichment $@$ & 8.32 & 2.34 & 9.45 & 1.46 & 0.61 & 2.22 \\
\hline$A^{\star} B$ & 14.3 & 4.15 & 20.7 & 3.17 & 0.69 & 5.44 \\
\hline$A^{*} \mathrm{C}$ & 11.8 & 3.31 & 13.4 & 2.07 & 0.86 & 3.14 \\
\hline $\mathrm{B}^{\star} \mathrm{C}$ & 11.8 & 3.31 & 13.4 & 2.07 & 0.86 & 3.14 \\
\hline$A^{*} B^{*} C$ & 16.6 & 4.68 & 18.9 & 2.93 & 1.22 & 4.44 \\
\hline
\end{tabular}

RSC: Rice straw compost, FYM: farmyard manure, Ma: macronutrients, Mi: micronutrients, ERSC: enriched rice straw compost, EFYM: enriched farmyard manure, NM: natural minerals, OS: organic sources, EOS: enriched organic sources

Of course, weathering process can be further mediated by organisms and their metabolites through respiration of plant roots and microbial degradation of organic matter, which can elevate carbonic acid concentrations in the soils and ground water, leading to an increase in the weathering rates of minerals (Badr, 2006). These increases in N, P and $\mathrm{K}$ uptake by wheat straw recorded $33.9 \%, 25.0 \%$ and $29.6 \%$ against $41.5 \%$, 
$38.3 \%$ and $38.5 \%$ for maize straw; the increases for wheat grain, on the other hand, recorded $52.8 \%, 65.6 \%$ and $51.8 \%$ against $26.5 \%, 20.4 \%$ and $20.4 \%$ for maize grains, as compared to application organic source alone. Treatments may be arranged as follows: enriched organic source (EOS) > organic source enriched with macronutrients $(\mathrm{OS}+\mathrm{Ma})>$ organic source enriched with micronutrients (OS $+\mathrm{Mi})>$ organic source alone (OS). Behavior of nutrient uptake followed the same trend of those obtained for yield components at the studied seasons. These results agree with those obtained by Hassan et al., (2010) who found that urea-formaldehyde treatments had a positive effect on plant growth parameters, also enhanced N, P and $\mathrm{K}$ contents in leaves, especially grape and date palm seedlings. Hellal et al., (2009) reported the role of applied natural alternatives fertilizers (rock phosphate and feldspar) on the N,P and K uptake by bean seeds; the highest values were recorded under feldspar treatment except of $P$ which was logically observed after rock phosphate treatment. However, this result indicates that a major portion of $\mathrm{K}$ present in feldspar mineral as well as in the organic material became available for uptake and contributed considerably towards the nutritional requirements of the crop. Similar result was obtained by Badr (2006) who added that this increase in uptake was due to reduced loss of nutrients primarily because of the presence of organic materials having chelating properties.

Finally, it may be worth to mention that responses of all evaluated parameters to all studied treatments were almost similar. In spite of that, exception was encountered with the studied crops yield, wheat being different from that of corn.

\section{CONCLUSIONS}

The benefits of this enriched rice straw compost (ERSC) demonstrated the possibility of sustained agronomic performance of both wheat and maize as well as reduction for the cost of cultivation through the use of cheep rock phosphate and feldspar. Mixing of feldspar and rock phosphate with rice straw compost, in the fields, was found to reduce leaching losses of nutrients from applied materials. Moreover, results also showed general high significant increases in available N, P and $\mathrm{K}$ in the soils as well as yield components and macronutrients uptake for straw and grains of both studied crops due to the applications of enriched rice straw compost (ERSC) in presence of inoculation as compared to rice straw compost alone. Except for yield of wheat, similar trend was attained. Accordingly, for the calcareous soil the enriched rice straw compost (ERSC) can be used as a source of fertilization in presence of the nutrients dissolving bacteria; such practice appears to be environmentally safe.

\section{Acknowledgment}

The authoresses wish to express their sincere gratitude and appreciation to the Development of Soil Conditioners Project, Dept. of Physics \& Chemistry of Soil, Soils, Water and Environ. Res. Inst., Agric. Res. Center (ARC), Giza, Egypt, for introducing all facilities needed to accomplish this study. 


\section{REFERENCES}

Abd El-Hamid, M.T.; Horiuchi, T. and Oba, S. (2004). Composting of rice straw with oilseed rape cake and poultry manure and its effects on faba bean growth and soil properties. Biores. Technol., 93: 183-189.

Abdel Wahab , A.; Biomy, A.H. and El-Farghal W. M. (2003). Effect of some natural soil amendments on biological nitrogen fixation, growth and grain yield of pea plants grown on sandy soils. Fayoum J. Agric . Res. and Environ., 17: 1-8.

Ali, Laila, K. M. (2001). "Use of improved organic fertilizers as nutrients sources". Ph.D. Thesis, Fac. Agric., Ain Shams Univ., Cairo.

Ali, Laila, K. M.; El-Etr, Wafaa, T. and El Khatib Elham, I. (2003). Evaluation of application of bacterial inocula for rice straw during compost process under aerobic conditions. J. Agric. Sci., Mansoura Univ., 28: 57875801.

Badr, M.A. (2006). Efficiency of K-feldspar combined with organic materials and silicate dissolving bacteria on tomato yield. J. Appi. Sci. Res. 2: 1191-1198.

Badr, M.A.; Shafei, A.M. and Sharaf El-Deen, S.H. (2006). The dissolution of $\mathrm{K}$ and $\mathrm{P}$-bearing minerals by silicate dissolving bacteria and their effect on sorghum growth. Res. J. Agric. And Biol. Sci., 2: 5-11.

Basyouny, E.A. (2001). Plant response of fertilization in relation to micronutrients status in plant and soil. PP. 55-58. Ph.D. Thesis, Fac. Agric., Ain Shams Univ., Cairo, Egypt.

Buchholz, D.D. and Brown, J.R. (1993). Potassium in Missouri soils. Agric. Pub., pp. 9 \&185.

Cakmakcl, R.; Erat, M.; Erdogan, O.G. and Donmez, M.F. (2007). The influence of PGPR on growth parameters, antioxidant and pentose phosphate oxidative cycle enzymes in wheat and spinach plants. J. Plant. Nutr. and Soil Sci., 170: 288-295.

Cottenie, A.; Verloo, M.; Kiekns, L.; Velghe, G. and Camerlynek, R. (1982)." Chemical Analysis of Plants and Soils" Lab. Anal. And Agroch. State Univ., Ghent, Belgium.

Duponnois, R.; Aline, C.; Victor, II. And Jean, T. (2005). The mycrrhizal fungus Glomus intraradices and rock phosphate amendment influence on plant growth and microbial activity in the rhizosphere of Acocia holosericea. J. Soil Biol. Biochem. 37: 1460-1468.

Gupta, R.K.; Arora, B.R.; Sharma, K.N. and Ahluwalia, S.K. (2000). Influence of biogas slurry and farmyard manure application on the changes in soil fertility under rice - wheat sequence. J. Ind. Soc. Soil Sci., 48: 500-505.

Han, H.S. and Lee, K.D. (2005). Phosphate and potassium solubilizing bacteria effect on mineral uptake, soil availability and growth of eggplant. Res. J. Agric. And Biol. Sci., 1: 176-180.

Han, H.S.; Supanjani; and Lee, K.D. (2006). Effect of co-inoculation with phosphate and potassium solubilizing bacteria on mineral uptake and growth of pepper and cucumber. Plant Soil Environ. , 52: 130-136. 
Hassan, H.S.A.; Saleh, M.M.S. and Abd El-Kader, A.A. (2010). Growth and leaf mineral content of some fruit species seedlings as affected by a slow release nitrogen fertilizer. Res. J. Agric. Biol. Sci., 6: 417-423.

Hegazi, N.A. and Niemela, S. (1976). A note on the estimation of Azotobacter densities by membrane filter technique. J. Appl. Bacteriol. 41: 311.

Hegazi, N.A.; Hamza, M.A.; Osman, A.; Ali, S.; Sedik, M.Z. and Fayez, M. (1998). Modified combined carbon $\mathrm{N}$-deficient medium for isolation, enumeration and biomass production of diazotrophs. In: Malik A, Kauser, Sajjad Mirza M, editors. Nitrogen fixation with non-legume. London Kluwer Academic Publishers, pp 247-253.

Hellal, F.A. and Nagumo, F. (2009). The effect of phosphorcomposting on solubility from rockphosphate andits effect on maize growth in red soil of Ishgaki, Japan Japanese Soil Sci. Soc. Conf. Kyoto Univ., Japan. 15-17 Sep., 2009.

Hellal, F.A.; Abd El-Hady, M. and Ragab, A.A.M. (2009). Influence of organic amendments on nutrient availability and uptake by faba bean plants fertilized by rock phosphate and feldspar. American-Eurasian J. Agric. \& Environ. Sci. 6: 271-279.

Jagadeeswaran, R.; Murugappan, V.; Govindas-wamy, M. and Senthil Kumar, P.S. (2007). Influence of slow release fertilizer on soil nutrient availability under Turmeric (Curcuma Longa L.). Asi. J. Agric. Res., 1: 105-111.

Kirk, O. (1993). Encyclopedia of Chemical Technology. Controlled Release Technology. Fourth ed., John Wiley and Sons Inc. 7: 251-271.

Kulikova, N.A.; Stepanova, E.V. and Koroleva, O.V. (2002). Mitigating activity of humic substances: Direct influence on biota. In: use of humic substances to remediate polluted environments: from theory to practice, NATO science series IV: earth and environment series, perminova, kluwer, I. V. (Eds.). Acad. Pupl., U.S.A., ISBN: 978140232509, 285-309.

Massoud, O.N.; Morsy, Ebtsam M. and El-Batanony Nadia, H. (2009). Field response of snap bean (Phaseolus vulgaris L.) to $\mathrm{N}_{2}$-fixers Bacillus circulans and Arbuscular mycorrhizal fungi inoculation through accelerating rock phosphate and feldspar weathering. Aust. J. Basic and Appl. Sci., 3: 844-852.

Nishanth, D. and Biswas, D.R. (2007). Kinetics of phosphorus and potassium from rock phosphate and waste mica enriched compost and their effect on yield and nutrient uptake by wheat (Triticum aestivum). Bioresource technology. 99: 3342-3353.

Osman, S.M. and Abd El- Rahman, A.E.M. (2009). Effect of slow release nitrogen fertilization on growth and fruiting of guava under mid Sinai conditions. Aust. J. Basic and Appl. Sci., 3:4366-4375.

Page, A.L.; Miller, R.H. and Keeney, D.R. (1982). "Methods of Soil Analysis" Part for 2. Amer. Soc. Agron., Madison, Wisconsin, U.S.A. 
Palm, C.A.; Myers, R.J.K. and Nandwa, S.M. (1997). Combined use of organic and inorganic nutrient sources for soil fertilizer maintenance and replenishment. In Replenishing soil fertility in Africa: Buresh, R.J., Sanchez, P.A. and Calhoun, E., Eds.; Soil Sci. Soc. Amer. Sp. Publ., 51: 193-217.

Rabie, Kawthar A.E.; Manaf, H.H.; Gouda, Hasnaa A.H. and Shahat, I.M. (2010). Influence of compost and rock amendments on growth and active ingredients of safflower (Carthamus tinctorius L.). Aust. J. of Basic and Appl. Sci. 4: 1626-1631.

Ramilison, R. (2001). The effect of local rock phosphate fertilizer on yield of maize in P-deficient soils of the central plateau of Madagascar. Seventh Eastern and Southern Africa Regional Maize Conference, 394-398.

Seddik, Wafaa, M. A. (2001). Biological weathering of K-bearing minerals. PhD. Thesis, Fac. Agric., Ain Shams Univ., Egypt.

Selim, A.M. (2004). Response of wheat to different $\mathrm{N}$-application and irrigation systems under arid conditions. International Conf. on Water Resources and Arid Environment.

Sharma, C.M.; Kaul, S. and Bhardwal, S.K. (1995). "Agronomic effectiveness of udaipur rock phosphate as influenced by organics in wheat (Triticum aestivum) - maize (Zea mays) cropping sequence". Indian J. Agron., 40: 93-95.

Sheng, X.F.; He, L. Y. and Huang, W.Y. (2003). Conditions of releasing potassium by a silicate dissolving bacteria strain NBT. Agriculture Sciences. 1: 662-666.

Shetty, K.G.; Hetrick, B.A.D.; Figge, D.A.H. and Schwob, A.P. (1994). Effect of mycorrhizae and other soil microbes on revegetation of heavy metal contaminated mine soil. Environ. Pollut., 86: 181-188.

Singh, M.; Singh, V.P. and Keddy, D.D. (2002). Potassium balance and release kinetics under continuous rice-wheat cropping system in vertisol. Field Crop Res., 77: 81-91.

Snedecor, G.W. and Cochran, W.G. (1980). Statistical Methods. $7^{\text {th }}$ Edition. lowa State Univ. Press., Ames., IA., U.S.A.

Stryiakova, I.; Styriak,I.; Galko,I.; Ilradial, D. and Bezdieak, P. (2003). The release of iron bearing minerals and dissolution of feldspar by heterotrophic bacteria of Bacillus spp. Ccrmics Silicaty. 47: 20-26.

Sugumaran, P. and Janarthanam, B. (2007). Solubilization of potassium containing minerals by bacteria and their effect on plant growth. World J. Agric. Sci., 3: 350-355.

Wahba, M.M. and Darwish, Kh.M. (2008). Improving the availability of potassium from feldspar in sandy and calcareous soils, Egypt. J. Soil Sci., 48: 393-398.

Wang, F.L. and Alva, A.K. (1996). Leaching of nitrogen from slow- release urea sources in sandy soils. Soil Sci. Soc. Amer. J., 60: 1454-1458.

Welch, S.A. and Ullman, W.J. (1993). The effect of organic acid on plagioclase dissolution rates and stoichiometry. Geochim. Cosmochim. Acta. 57: 2725-2736. 


\section{El-Etr, Wafaa T. et al.}

Wu, S.C.; Cao, Z.H.; Li, Z.G.; Cheung, K.C. and Wong, M. H. (2005). Effects of biofertilizer containing $\mathrm{N}$-fixer, $\mathrm{P}$ and $\mathrm{K}$ solubilizers and AM fungi on maize growth: a greenhouse trial. Geoderma. 125:155-166.

Youssef, Hanan, H. (1993). Improving efficiency of nitrogen fixing bacteria associated with field crops. M. Sc. Thesis, Faculty of Agric., Cairo University.

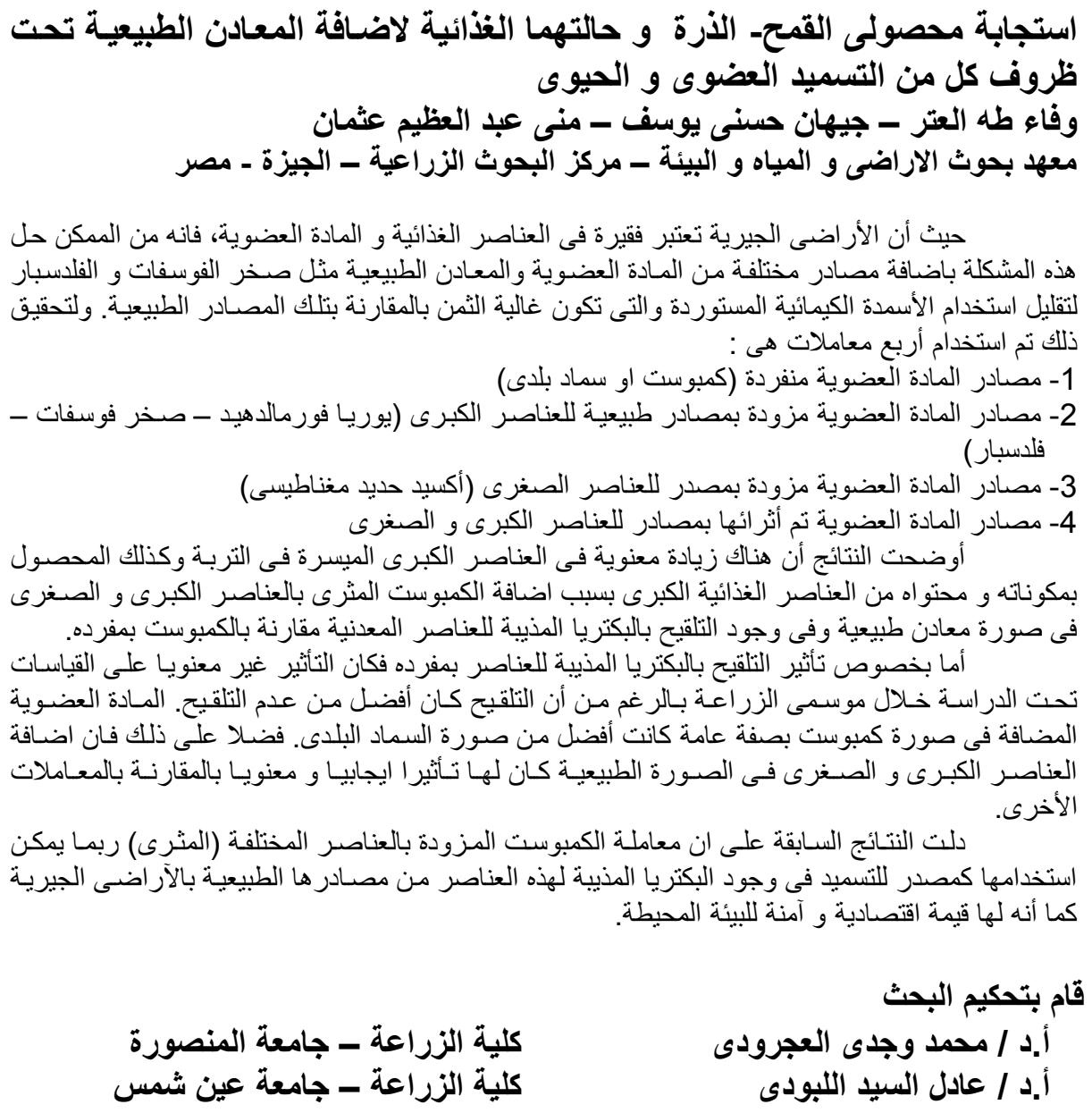

